Published in Review of Religious Research 55:297-317.

https://link.springer.com/article/10.1007/s13644-012-0066-1

\title{
Religious Organizations and Homosexuality: The Acceptance of Gays and Lesbians in American Congregations
}

\author{
Andrew L. Whitehead \\ Clemson University
}

\begin{abstract}
The participation of gays and lesbians in all aspects of society is continually disputed in the United States. Religion is one of the key battlegrounds. The extent to which religious congregations include lesbians and gays in congregational life is vital to the wider debate over homosexuality because congregations consistently influence more Americans than any other voluntary social institution (Putnam 2000). Using nationally representative data from the 20062007 National Congregations Study this analysis investigates the level of acceptance of gays and lesbians within congregations as well as which congregations are most likely to allow lesbians and gays to become involved. I find that religious tradition, theological and political ideology, location, and demographic composition of congregations all influence the degree to which gays and lesbians are included into congregational life.
\end{abstract}

Keywords: homosexuality, congregations, religion, United States, gays, lesbians 


\section{INTRODUCTION}

The extent to which gays and lesbians are permitted to participate in social life is fiercely contested. For example, the battle in California over Proposition 8 and same-sex marriage, which began in late 2008, continues over three years later. Gay and lesbians' right to serve in the military is now recognized after almost 18 years of "Don't Ask, Don't Tell”. Included in these discussions is the level to which, or even if, religious organizations should embrace lesbians or gays in their midst. Questions concerning the ordination of gays and lesbians, the blessing of same-sex unions, or whether religious organizations will accept lesbians and gays as equal members repeatedly arise. These questions and debates are even more influential when considering that the most pervasive form of religious organization, the congregation, consistently influences more Americans than any other voluntary social organization (Ammerman 1997; Chaves 2004, 2011; Putnam 2000). Therefore, if and to what extent religious congregations accept gays and lesbians will communicate a great deal about the access of this socially relevant minority to a significant organizational feature of American society.

This study aims to provide insight into how a significant social setting, the religious congregation, is navigating this salient issue. It will present evidence of where religious congregations stand on the issue and what these stances might mean for gays and lesbians in America. To date, there is little known at a national level about the extent to which congregations are open and welcoming toward gays and lesbians. A number of studies utilize denominations, small samples of congregations, or clergy as units of analysis (e.g. Van Geest 2007a; Cadge, Day, and Wildeman 2007; Olson and Cadge 2002). The absence of a nationally representative sample of congregations leaves some questions unanswered. How many congregations allow for lesbians and gays to become members or even leaders? How many congregations officially 
welcome gays and lesbians into their midst? What types of congregations are more likely to allow for the full participation of lesbians and gays? Utilizing a nationally representative sample of religious congregations in America, this research contributes to the study of religious organizations and their responses to homosexuality by investigating the extent to which gays and lesbians are allowed to participate in congregations as well as the organizational correlates of more accepting congregations.

\section{RELIGION, CONGREGATIONS, AND HOMOSEXUALITY}

The amount of research concerning religious organizations and the issue of homosexuality has grown in the last decade and a half. A host of studies focused on the national debates about homosexuality at the denominational level (Beuttler 1999; Burgess 1999; Cadge 2002; Kapinus, Kraus, and Flowers 2010; Koch and Curry 2000; Rogers 1999; Scheitle, Merino, and Moore 2010; Van Geest 2007a, 2007b; Wellman 1999; Wood and Bloch 1995). This line of research traces the change in denominational stances toward gays and lesbians and their inclusion in congregational life. It describes how the issue of homosexuality is framed by different denominations, depending upon what the issue might mean for that particular religious organization. Researchers have also traced the diffusion of certain denominational programs concerned with being "Open and Affirming" and the changing understanding of that designation by the congregations that adopt the label (Scheitle et al. 2010). Another strand of research works to bridge denominations and congregations (Cadge et al. 2007; Cadge, Olson, and Wildeman 2008). These studies show that congregations within denominations that provided structured material for the congregations to work through experienced less conflict. Essentially, denominations influence congregations within their fold, but not to the extent that some might assume. Congregations, in many instances, chart their own course. Thus, stances toward gays 
and lesbians can differ between congregations within the same religious tradition (Cadge et al. 2007; Cadge et al. 2008).

In addition to congregational and denominational studies, the clergy and their responses to homosexuality also received attention (Cadge and Wildeman 2008; Cadge et al. 2012; Comstock 2001; Djupe, Olson, and Gilbert 2006; Olson and Cadge 2002). For the most part clergy are hesitant to raise the issue of homosexuality due to fear of conflict. Such conflict might serve to alienate portions of the congregation leading them to leave (Olson and Cadge 2002). However, in some congregations homosexuality is commonly discussed due to the relative scarcity of gays and lesbians attending those congregations. There is relatively little risk in the congregation retaining an oppositional stance (Wellman 1999). ${ }^{1}$ This research points out that there are also distinct differences between clergy of different religious traditions as well as between clergy within the same religious tradition. Finally, a number of ethnographic studies of various congregations point out how the surrounding ecology, demographic shifts, increased interpersonal contact with gays and lesbians at worship, or the views of the clergy can and do influence a congregation's response to or the form of the conflict over homosexuality (Ammerman 1997, 2005; Becker 1999; Hartman 1996; Moon 2004; Warner 1995).

The scarcity of nationally representative data on religious congregations places limits on the degree to which researchers can investigate the organizational correlates of congregational stances toward gay men and lesbians. For example, we do not know the overall degree to which religious congregations are open toward lesbians and gays in general. Nevertheless, previous research on denominations, regional samples of congregations, and clergy can provide some insight into factors that may prove important in predicting congregational stances.

\footnotetext{
${ }^{1}$ I am thankful to a reviewer for highlighting this point.
} 
First, religious tradition should be strongly associated with certain stances toward gays and lesbians. Mainline Protestant congregations and Catholic parishes are more likely to be welcoming of lesbians and gay men than Evangelical and Black Protestant congregations (Ammerman 2005; Button, Rienzo, and Wald 1997; Gay and Ellison 1993; Van Geest 2007b). Mainline Protestants and Catholics are closer to the center of American religion and are therefore more likely to reflect the beliefs and attitudes of the wider culture (Roof and McKinney 1987). The increasing acceptance of lesbians and gays in the United States is well established (Andersen and Fetner 2008). Catholics, while more conservative on some issues, tend to accept gays and lesbians because of their desire to include disparate groups within the fold (Button et al. 1997). Evidence of the influence of religious tradition at the individual level is also well-established (Cochran and Beeghley 1991; Greeley and Hout 2006; Olson, Cadge, and Harrison 2006). Beyond religious tradition, the theological and political ideologies of a congregation influence the extent to which congregations are willing to involve lesbians and gay men in congregational life (Ammerman 1997; Becker 1999). Theological ideologies can be particularly predictive (Ammerman 1997; Becker 1999; Button et al. 1997; Ellingson et al. 2001; Wellman 1999). By identifying as theologically conservative, moderate, or liberal, religious organizations are making a statement about where the congregation stands relative to the perceived norm. The increasing salience of theological ideologies and the subsequent rearranging along those lines led to what some considered a restructuring of American religion (Roof and McKinney 1987; Wuthnow 1988). The influence of theological ideology on attitudes toward lesbians and gays exists at the individual level as well. Individuals who identify as more theologically traditional or conservative tend to be less favorable toward homosexuality (Burdette, Ellison, and Hill 2005; Froese, Bader, and Smith 2008; Whitehead 2010). Theologically traditional individuals and 
congregations are more likely to interpret their sacred scriptures in a more literal fashion. This leads them to apply passages interpreted as denouncements of homosexuality to the present context.

The political ideology of a congregation is also associated with its stance on homosexuality (Becker 1999; Wald, Button, and Rienzo 1996; Wald, Owen, and Hill 1988). Congregations that align themselves as politically liberal are more inclined to be favorable toward gays and lesbians compared to politically conservative or moderate congregations. Political liberalism in the United States has become a marker of those groups or individuals who aspire to equality for all individuals. In this way, congregations who identify as such are making a statement concerning their level of tolerance. The effect of political ideology on attitudes toward gay and lesbian persons is strongly supported at the individual level as well (Hill, Moulton, and Burdette 2004; Sherkat et al. 2011). Prior research suggests the following concerning congregational stances toward gays and lesbians:

H1: $\quad$ Mainline Protestant congregations and Catholic parishes will be more likely to allow the full inclusion of lesbians and gays into congregational life than Evangelical and Black Protestant congregations

H2: $\quad$ Theologically liberal congregations will be more likely to allow the full inclusion of gays and lesbians into congregational life than theologically moderate or conservative congregations.

H3: $\quad$ Politically liberal congregations will be more likely to allow the full inclusion of lesbians and gay men into congregational life than politically moderate or conservative congregations.

Beyond religious tradition and theological and political ideology, a number of studies highlight the importance of demographic and structural differences when investigating congregational positions on moral issues (Ammerman 1997; Becker 1999; Hartman 1996). The education level of the clergy might influence congregational stances toward lesbians and gays. 
Historical accounts of organized religion in the United States reveal a widespread assumption that clergy who obtain higher levels of education tend to move toward a more critical interpretation of sacred scriptures and more engagement with secular society (Finke and Stark 2006). Subsequent research demonstrates that the professionalization of clergy does influence views on how congregations should relate to the cultural context within which they find themselves (Finke and Dougherty 2002; Finke and Stark 2006; Stark and Finke 2000). The liberalizing effect of education should also exert an effect on congregational stances toward gays and lesbians through the education level of congregants. At the individual level, higher levels of education are positively associated with more favorable views toward lesbians and gay men (Haider-Markel and Joslyn 2008; Herek and Capitanio 1995). Increasing education tends to liberalize cultural views, reduce levels of religious orthodoxy, and encourage a cultural broadening that places individuals in more diverse networks. These all lead to greater levels of tolerance toward out-groups (Davis and Robinson 1996; Hunter 1992).

The percentage of females in a congregation ought to also influence its propensity toward allowing gays and lesbians to take part in congregational life. That females are more favorable toward lesbians and gay men is established in previous research (Finlay and Walther 2003; Herek 1988, 2002; Herek and Capitanio 1995; LaMar and Kite 1998). Likewise, the age structure of a congregation should influence the level to which lesbians and gays are permitted to be involved. Older individuals tend to be less favorable toward lesbians and gays (HaiderMarkel and Joslyn 2008; LaMar and Kite 1998). The region within which a congregation is located may also be important due to the propensity of individuals residing in the South to hold less favorable views of gays and lesbians compared to the other regions of the country (Ammerman 1997; Herek 1988; Sherkat et al. 2011). Beyond the effect of regional religious 
culture, "cultural homogeneity" and limited interaction with "minority sociopolitical views" and "alternative lifestyles" within the South also lead to such regional differences (Ellison and Musick 1993:389). The community context within which a congregation resides may play a role too. Those residing in mostly urban areas are usually more favorable regarding gays and lesbians (Ammerman 1997). In fact, case studies of a handful of congregations responding to lesbians and gays in their midst tended to be located in more urban areas. Their response to homosexuality became more salient because of the higher concentration of lesbians and gays residing in those urban areas (Ammerman 1997). Previous research generates the following expectations concerning the inclusion of gays and lesbians in congregational life:

H4: $\quad$ Congregations whose senior clergy has an advanced degree will be more likely to allow the full inclusion of lesbians and gays into congregational life.

H5: $\quad$ Congregations with a higher percentage of college-educated congregants will be more likely to allow the full inclusion of gay men and lesbians into congregational life.

H6: $\quad$ Congregations with a higher percentage of female congregants will be more likely to allow the full inclusion of lesbians and gays into congregational life.

H7: $\quad$ Congregations with a higher percentage of young people will be more likely to allow the full inclusion of gays and lesbians into congregational life.

H8: $\quad$ Congregations located in the South will be less likely to allow the full inclusion of lesbians and gays into congregational life compared to congregations in the East, Midwest, or West.

H9: $\quad$ Congregations located in urban areas will be more likely to allow the full inclusion of gays and lesbians into congregational life compared to congregations in non-urban areas.

\section{DATA}

To test these hypotheses this study draws on data from the second wave (2006-2007) of the National Congregations Study (NCS-II). The NCS-II is a nationally representative sample of 1,506 congregations in the United States that essentially replicates the 1998 NCS (Chaves and 
Anderson, 2008). The NCS-II also contains a panel component that draws a stratified random sample of 326 congregations that appeared in the 1998 NCS. In sum, data from 1,506 congregations was gathered with 252 from the panel sample, 1,250 that were newly nominated, and four that were both in the panel and also newly nominated. The surveys were completed using a 45-minute interview with one key informant from the congregation. Over 80 percent of key informant interviews were with clergy or congregational staff. The remaining interviews were with non-staff congregational leaders. These interviews were completed in both English and Spanish. The overall response rate for the sample was 78 percent. $^{2}$ The data are made available at the Association of Religion Data Archives (www.theARDA.com).

There are several well-documented weaknesses concerning the key informant survey methodology. These include the propensity of key informants to overestimate the similarity of opinions within an organization, the key informant may not know what is actually taking place within the congregation, or the key informant may be simply reporting what the congregation's ideal stance would be. Researchers should keep these weaknesses in mind and interpret the results of this study cautiously (Frenk et al. 2011; Schwadel and Dougherty 2010). However, while such loose coupling between what the key informant is reporting and what is actually taking place within the congregation may exist, there is evidence for the reliability of the key informant strategy, especially concerning the NCS (see Beyerlein and Chaves 2003; Chaves et al. 1999; Frenk et al. 2011). Furthermore, while the key informant methodology utilized in the NCS-II is not without weakness, the NCS-II is still a significant source of information concerning the stances American congregations take concerning the inclusion of gays and

\footnotetext{
${ }^{2}$ See Chaves and Anderson (2008) for a complete description of the NCS-II.
} 
lesbians. While not perfect, the NCS-II provides at least an indication of congregational responses to homosexuality at the national level.

The NCS-II is ideal for this study because it is the only nationally representative sample of congregations available that asks questions concerning congregational stances toward lesbians and gays. ${ }^{3}$ It also contains questions on the demographic make-up, structure, organizational activities, and programming of each congregation. These data allow for a level of generalizability that will extend past findings concerning which types of congregations accept gays and lesbians and the level to which they do so.

\section{Dependent Variables}

The three dependent variables used in this analysis measure the extent to which congregations are open to lesbians and gays. The first focuses upon whether congregations would allow gay men and lesbians to become members. The question asks, "Would the following types of people be permitted to be full-fledged members of your congregation: An openly gay or lesbian couple in a committed relationship?" The second question goes a step further by asking if gay and lesbian couples would be allowed leadership positions within the congregation. It asks, "Regarding leadership, if they were otherwise qualified, would the following types of people be permitted to hold all of the volunteer leadership positions open to other members: An openly gay or lesbian couple in a committed relationship?" The final

\footnotetext{
${ }^{3}$ The 2001 US Congregational Life Survey is also nationally representative and contains one question on the congregational survey pertaining to homosexuality that asks, "Does your congregation or denomination have any special rules or prohibitions regarding the following? Homosexual behavior." The question wording inhibits straightforward interpretation however because we do not know if the rules and prohibitions the respondent is alluding to emanate from the denomination or congregation, or both. The questions contained in the NCS (2006-2007) are more straightforward concerning the congregation's stance and indicate exactly how and the extent to which the congregation prohibits homosexuality.
} 
dependent variable accounts for the presence of a formal welcome statement toward gays and lesbians adopted by the congregation. In many cases such a statement could be only symbolic, but in others it may actually alter the culture of a congregation leading it to be more accepting of gays and lesbians (Becker 1999; Button et al. 1997; Scheitle et al. 2010). A formal declaration by the congregation is in many ways even more symbolic than allowing gays and lesbians to be members or leaders. Possible responses for all questions were either "yes" (coded 1) or "no" ( coded 0).

\section{Independent Variables}

To measure religious tradition, a series of dichotomous variables was created according to the RELTRAD typology (Steensland et al. 2000). Congregations were coded as Evangelical Protestant, Mainline Protestant, Black Protestant, Catholic, Jewish, or Other. ${ }^{4}$ Mainline Protestant congregations serve as the contrast category in multivariate analyses.

A measure of both religious and political ideology is included in the analysis. Concerning religious ideology the NCS-II asks, "Theologically speaking, would your congregation be considered more on the conservative side, more on the liberal side, or right in the middle?" For the political ideology measure it asks, "Politically speaking, would your congregation be considered more on the conservative side, more on the liberal side, or right in the middle?" Possible responses for both questions were "More on the conservative side" (1), "Right in the middle" (2), or "More on the liberal side" (3). Dummy variables were created for each response. Liberal congregations serve as the contrast category in multivariate analyses for both religious and political ideology variables.

\footnotetext{
${ }^{4}$ The Jewish category was later combined with the Other category due to such a small number of synagogues present in the NCS-II.
} 
A number of congregational characteristics are also employed in the analysis. A measure of the educational attainment of the senior clergy is included. This measure is dichotomous where 1 = senior clergy has graduated from a seminary or theological school. The percent of the congregation that is female, the percent under 35 years of age, and the percent with a BA degree are all included as well. Congregations in the South are used as the contrast category compared to congregations in the East, Midwest, and West and urban versus non-urban is used to account for size of place. The size of the congregation and the year the congregation was founded are incorporated in the models as controls. The log of the size variable is used in all analyses due to the skewed distribution of congregations on that variable.

\section{METHOD}

I begin by presenting descriptive statistics to provide a picture of how U.S. congregations respond to homosexuality. I will provide both the percent of congregations that have a formal welcome statement and allow gays and lesbians to become members and leaders as well as the percent of regular worship service attenders that attend those congregations. ${ }^{5}$ Both of these viewpoints are substantively interesting. I then present bivariate analyses of the independent and dependent variables. Finally, I move on to multivariate analyses to determine which congregational characteristics are most predictive of more open stances toward gays and lesbians. With the exception of the region and religious tradition measures, all other variables

\footnotetext{
${ }^{5}$ Two weights are employed in the descriptive and bivariate analyses of the NCS-II data. Because the NCS-II is a probability-proportional-to-size sample, the percentage of regular attenders within various congregations is obtained by using a weight that accounts for the fact that some congregations were nominated by more than one person. To obtain the percent of congregations with various characteristics, a weight is utilized that weighs congregations inversely proportional to their size. See Chaves and Anderson (2008) for details.
} 
included in the model had cases with missing information. ${ }^{6}$ I used multiple imputation (MI) to account for the missing data (Rubin 1987, 1996). ${ }^{7}$ Due to the coding of both dependent variables, binary logistic regression is utilized in the multivariate models. I report standardized coefficients in order to compare effects across the various measures [ $B_{y x}^{*}=b_{y x}\left(s_{x /} s_{y}\right)$ ] (Pampel 2000). ${ }^{8}$

\section{RESULTS}

Table 1 displays the extent to which gays and lesbians in committed relationships are accepted in congregations in the United States. The first column provides a look at how many congregations exhibit these characteristics. The second column tells us what percentage of regular attenders are found within these congregations. Therefore, we can determine not only if a congregational stance is widespread at the organizational level but also if it is influencing a large percentage of regular attenders. ${ }^{9}$ Only 37.4 percent of congregations in the United States allow gays and lesbians in committed relationships to become members with a smaller

\footnotetext{
${ }^{6}$ Of the 1,506 congregations in the NCS (2006-2007), 21 percent were missing on at least one variable included in the model, leaving under 1,200 congregations with usable data. Subsequent analyses performed on those congregations remaining after listwise deletion revealed that they were significantly more likely to allow those in same-sex relationships to become leaders compared to the missing congregations. There was no significant difference concerning allowing lesbians and gay men to become members however.

${ }^{7}$ The MI procedure generates five imputations using multiple Markov Chains based on all variables included in each model, resulting in an overall $\mathrm{N}$ of 7,530 (1,506 X 5). The results reported in each table are from the MIANALYZE procedure in SAS. This procedure combines all of the results from each of the five imputations resulting in overall estimates, standard errors, and significance levels. The Proportional Reduction in Error (PRE) reported in Table 4 for each model is the average of the PRE for each individual iteration.

${ }^{8}$ I follow Pampel's (2000) assumption that the standard deviation of logit $(y)=1.8138$.

${ }^{9}$ Interpreting the differences between the two is fairly straightforward: if the percentage in the percent attender column is larger than the percentage in the percent congregations column, larger congregations are more likely to exhibit the characteristic in question; conversely, if the percentage in the percent congregations column is larger than the percent attender column the congregations exhibiting the characteristic tend to be smaller.
} 
percentage of congregations, 18.7, allowing those individuals to hold leadership positions. An even smaller percentage of congregations have adopted formal statements of welcoming (5.7 percent). Table 1 also shows that almost 50 percent of regular attenders are in congregations where same-sex couples would be allowed to become members. However, only 22.5 percent of regular attenders are in congregations where gay and lesbian couples are allowed to lead in some way. A little over eight percent (8.3) of regular attenders are in a congregation with a welcome statement. These differences in percentages for congregations versus attenders indicate that larger congregations are more accommodating of gays and lesbians. Unsurprisingly, allowing lesbians and gays to lead is accepted much less frequently than allowing them to become members. Table 1 clearly demonstrates that on the whole, congregations in the United States are decidedly against the full inclusion of gay and lesbian couples into congregational life.

[ Table 1 about here ]

Tables 2 and 3 display the bivariate relationships between the level of acceptance of lesbian and gay couples in congregations and each of the independent variables included in the analysis. ${ }^{10}$ Table 2 includes all of the categorical or dichotomous variables and the data is weighted to obtain the percentage of congregations that exhibit each characteristic. ${ }^{11}$ Table 3 displays the bivariate analyses for the continuous measures and utilizes the same weight

\footnotetext{
${ }^{10}$ The results for the bivariate analyses found in Tables 2 and 3 utilize the percent congregation weight described in footnote 5 . Results using the percent attender weight are not displayed because the focus of this investigation concerns religious organizations first and foremost. Results that employ the percent attender weight are available from the author upon request. ${ }^{11} \mathrm{Chi}$-square tests for significance were performed using unweighted data. The weight utilized in Tables 2 and 3 for the percentages and means displayed weighs the data inversely proportional to congregation size and it is inappropriate to calculate chi-square tests on data weighted in this fashion. However, tests for significance can be performed when weighing the data to account for duplicate nominations which produces the percentage of attenders results discussed in footnote 5 . These tests produced identical results to the unweighted data.
} 
employed in Table 2. These analyses provide a first look into which congregations are more likely to allow gay and lesbian couples to be members and leaders.

Unsurprisingly, religious tradition is highly predictive of whether a congregation is inclusive of same-sex couples. Only 15.2 percent of Evangelical Protestant congregations allow gay and lesbian couples to become members compared to 67.3 percent of Mainline Protestant congregations, 44.2 percent of Black Protestant congregations, and 74 percent of Catholic congregations. Similarly, only 3.8 percent of Evangelical Protestant congregations allow lesbians and gays in committed relationships to lead. The percentage of Black Protestant congregations that grant lesbians and gays leadership positions aligns closely to the number of Evangelical Protestant congregations with only 9.5 percent doing so. This is a precipitous drop from the percentage of Black Protestant congregations that are willing to include individuals in same-sex relationships as members. With 52.6 percent of congregations allowing lesbians and gays leadership positions, Mainline Protestants are the most inclusive religious tradition. Catholic parishes allow those in same-sex relationships to lead at a level much closer to Mainline Protestants compared to Evangelical or Black Protestants. Compared to the percentage of Catholic parishes that allow individuals in committed same-sex relationships to become members however, there is a noteworthy drop in the percentage of Catholic parishes allowing these individuals to be leaders. The difference among religious traditions persists when looking at the adoption of a welcome statement. Over 14 percent of Mainline Protestant congregations report having a welcome statement, while only 5 percent of Catholic parishes, 4 percent of Evangelical Protestant congregations, and not quite 2 percent of Black Protestant congregations report the same.

[ Table 2 about here ] 
Congregations that identify as liberal in their religious and political ideologies are much more likely to adopt a welcome statement as well as allow individuals in same-sex relationships to become members or leaders. Over 80 percent of theologically liberal congregations allow gays and lesbians to become members, 60 percent allow them to lead, and almost 30 percent have welcome statements. Conversely, conservative $(26.2,11.6,3.7)$ or moderate $(49.5,21.9$, 3.5) congregations are much less likely to include lesbians and gays in congregational life or formally welcome them. The results for political ideology are almost identical to theological ideology. A much greater percentage of liberal congregations allow those in same-sex relationships to be members (78.2) and leaders (60.9) and adopt welcome statements (30.9) compared to the moderate $(47.8,27.4,3.3)$ and conservative $(26.5,8.2,4.0)$ congregations.

The liberalizing effect of an advanced degree for the senior clergy of a congregation is visible as well with almost 44 percent of congregations in this group allowing lesbians and gays to be members compared to only 30 percent in congregations where the clergy does not hold an advanced degree. The differences are even more obvious when comparing the two groups on allowing those in same-sex relationships to hold leadership positions. While over a quarter of congregations with senior clergy who hold an advanced degree allow gays and lesbians in committed relationships to lead, only 4.1 percent of congregations whose senior clergy has no advanced degree do so. Regarding welcome statements the differences by clergy education are similar but not quite so dramatic. Approximately 7 percent of congregations with seminary trained clergy have welcome statements compared to 4 percent for the rest.

Congregations in the East tend to be the most open toward allowing individuals in samesex relationships to become members and lead and adopt welcome statements. Congregations in the West are the next most open followed by congregations in the Midwest. Congregations in 
the South are the most opposed toward the inclusion of lesbian and gay couples with only 35 percent allowing them to become members and only 10 percent allowing them to lead. Only 3.7 percent of congregations in the South report having a welcome statement. Regarding community characteristics, congregations in urban areas are much more likely to allow lesbians and gays to become members and lead compared to congregations in non-urban areas. Conversely, slightly fewer urban congregations have formal welcome statements (5.4) than non-urban congregations (5.9).

Turning to Table 3 we find that congregational demographic measures are significantly associated with their openness toward those in same-sex relationships. Congregations that allow gay men and lesbians in committed relationships to be members and leaders and have welcome statements tend to have more individuals with bachelor's degrees. Thus, as congregations' mean educational attainment level increases, their propensity to more fully include those with a partner of the same sex in congregational life increases as well.

\section{[ Table 3 about here ]}

Somewhat surprisingly, as the percentage of the congregation that is under 35 increases, congregations are more likely to exclude gays and lesbians in committed relationships from membership and leadership roles and not have a welcome statement. This relationship is a bit counterintuitive because younger cohorts are usually more accepting of homosexuality. One explanation could be that Evangelical and Black Protestant congregations tend to be younger than other religious traditions and also more conservative. This possible interpretation will be tested in the multivariate analyses that follow. Congregations that report having a welcome statement and allow lesbian and gay couples to be members and leaders are usually larger and founded earlier. Finally, congregations that permit gay men and lesbians to lead tend to have a 
higher percentage of females. This relationship does not hold true when considering congregations that have welcome statements or who allow those in same-sex relationships to be members, however.

Using these bivariate relationships as a guide, I move on to a multivariate analysis of congregational stances toward lesbians and gays. Table 4 presents results of logistic regression analyses. Unsurprisingly, religious tradition is highly predictive of permitting those with partners of the same sex to become members, lead within the church, and adopting a welcome statement. Both Evangelical and Black Protestants are much less likely to incorporate lesbians and gays into congregational life compared to Mainline Protestants. Catholic congregations, though, are no more or less likely than Mainline Protestant congregations to consent to gay men and lesbians being members. Differences between Mainline and Catholic congregations do arise concerning allowing lesbians and gays to hold leadership positions or adopting a formal statement of welcoming, with Catholics being less likely to do so. These results affirm the first hypothesis and closely align with previous research. Theologically conservative and moderate congregations are much less likely to include same-sex couples in congregational life than theologically liberal congregations. They are also less likely to adopt a welcome statement. Therefore, hypothesis 2 finds support. Regarding political ideology, conservative and moderate congregations are each less likely than liberal congregations to adopt a welcome statement or to tolerate lesbians and gays becoming members or leaders, supporting hypothesis 3 .

\section{[ Table 4 about here ]}

Turning to the effects of various congregational characteristics, congregations whose senior clergy holds an advanced degree are no more likely to accept gay men and lesbians in committed relationships as members or to adopt a welcome statement. However, these 
congregations are more likely to allow those in same-sex partnerships to lead within the congregation, regardless of religious tradition or the theological and political ideology of the congregation. This finding is in partial agreement with the prediction of hypothesis 4 . Congregations with a greater percentage of individuals with a bachelor's degree are more likely to allow lesbians and gay men to be both members and leaders, but no more likely to adopt a welcome statement. This provides limited support for the fifth hypothesis. Supporting hypothesis 6 to a degree, a higher percentage of females is positively associated with allowing those in committed same-sex relationships to become members but is not significantly associated with allowing them to lead or adopting a welcome statement. An increase in the percentage of congregants under 35 years of age is not associated with any of the dependent variables. This finding opposes the bivariate relationships discussed previously and the prediction made in hypothesis 7. This is most likely due to controlling the effects of religious tradition. Evangelical and Black Protestant congregations are usually younger regarding congregant's mean age and much more conservative than Mainline congregations.

Concerning whether or not congregations adopt a welcome statement or allow lesbian and gay couples to become members, no region of the country is significantly different from the South. Conversely, congregations in the Midwest and West are each more likely to consent to gays and lesbians having the right to lead compared to congregations in the South. These findings offer limited confirmation of hypothesis 8 . Contrary to the ninth hypothesis, net of all the other effects in the model, whether a congregation is in an urban location has no bearing on its propensity to allow lesbians and gays to become members or lead or adopt a formal welcome statement. Congregation size is significantly and positively associated with whether those in same-sex relationships are permitted to be members and if the congregation has a formal 
welcome statement, but size is not associated with letting lesbians and gays lead. When the congregation was founded is not significantly associated with either of the first two measures of congregational openness toward homosexuality but younger congregations are more likely to adopt a welcome statement.

\section{DISCUSSION}

These results demonstrate that a host of congregational features are important when considering congregational responses toward the full inclusion of gay men and lesbians. Accounting for religious tradition is essential. Evangelical and Black Protestant congregations are much less likely to adopt a welcome statement or allow gays and lesbians in committed relationships to become members or lead compared to Mainline Protestant congregations. This suggests that for Evangelical and Black Protestant religious organizations the issue of homosexuality serves as a boundary marker that operates to designate those who are "in" the group from those who are not. These clear boundaries encourage internal vitality and commitment to the group (Smith et al. 1998). Lesbians and gay men may provide a valuable out-group for these congregations because they rarely cross paths with these individuals generating few negative consequences for maintaining an oppositional stance (Wellman 1999).

Finding that Evangelicals are less likely to accept lesbians and gays compared to Mainline congregations confirms past research. The findings concerning Black Protestant congregations are noteworthy (though not unsurprising) considering that this religious tradition usually aligns with Evangelicals on moral issues but concerning issues of social justice they side more so with Mainline Protestants (Lincoln and Mamiya 1990). Because Black Protestant congregations are less likely than Mainline Protestant congregations to include lesbians and gays in congregational life signals that equality for gays and lesbians is defined as more of a moral 
issue rather than a civil rights or social justice concern. This suggests that in some way these congregations act as interpretive communities (Bartkowski 1996; McDaniel and Ellison 2008). For instance, African-Americans' higher levels of opposition toward same-sex unions can be traced to their greater levels of religious involvement (Sherkat, de Vries, Creek 2010). However, this finding also suggests that if the acceptance of homosexuality is in some way redefined as a social justice issue rather than strictly a moral issue, Black Protestant congregations may become more welcoming and the significance of homosexuality as a boundary marker may decline.

It is also important to recognize that there are no significant differences between Catholic parishes and Mainline congregations in their acceptance of those in same-sex relationships as members. This is somewhat surprising considering the Catholic Church's rather traditional stance toward other divisive issues like abortion. Button and colleagues (1997) explain the church's stance by pointing to Catholicism's strong emphasis on social justice. Likewise, Catholic interpretation of scripture concerning homosexuality distinguishes between orientation and behavior. In this way, some Catholic parishes work to enable gays and lesbians to live within the fold while not endorsing homosexuality per se (Ammerman 1997). The inclusion of gay men into Catholic life is documented in Ammerman's (1997) case study of St. Matthew's parish. However, Catholic parishes are less likely to allow gays and lesbians leadership positions or adopt a formal statement of welcoming however. There appears to be a limit to the level of involvement allowed lesbians and gays when comparing Catholic parishes to Mainline congregations.

Despite the powerful and predictably influential effect of religious tradition on a congregation's position concerning homosexuality, many congregations within the same religious tradition take different stances on the issue (Ammerman 2005). The results from the 
present investigation support this assertion: the theological and political ideology, demographic composition, and location of a congregation are all significantly associated with its acceptance of gays and lesbians in committed relationships beyond the effects of religious tradition.

Theological and political ideologies are essential. If a congregation identifies itself as theologically or politically liberal, it will be much more likely to accept homosexuality than a moderate or conservative congregation, no matter the religious tradition. For instance, a congregation could identify with the Catholic or Mainline Protestant traditions but the theological and political ideology of that congregation might lead it to stake out a position concerning homosexuality that is more similar to Evangelical or Black Protestant congregations. Furthermore, knowing a congregation's political ideology is important because it can influence the political views of congregants (Wald et al. 1988). It should be noted though that while congregations can act as political communities they do not necessarily engage in politics beyond a few particular forms of political action, depending on the religious tradition of which they are a part (Chaves 2004).

The demographic composition of a congregation is significantly associated with the level of acceptance of homosexuality as well. Prior research at the individual level on the liberalizing effect of education concerning attitudes toward gays and lesbians finds further confirmation here. Congregations that have more individuals with bachelor's degrees are more likely to allow samesex couples to become involved in congregational life at all levels. This is an important extension of individual level findings concerning the liberalizing effect of education. Higher mean levels of education seem to create contextual effects that can influence entire congregations (Stroope 2011). In this way, it is not only what an individual's level of education might be, but also those around the individual that create the group's stance. The changing 
ecology around a congregation could bring this dynamic into play. A community could begin to attract highly educated individuals because of new job opportunities and the constituency of the congregation might shift influencing its demographic composition. Qualitative studies of communities in flux support these possibilities (Ammerman 1997). It is significant, however, that congregations with many highly educated individuals are not any more likely to adopt a formal statement of welcoming, all else being equal.

Congregations with educated clergy are more likely to allow lesbians and gays in committed relationships to become leaders, but there are no differences in the propensity of the group to adopt a formal statement of welcoming or allow gays and lesbians to become members. Thus, the professionalization of the clergy is associated with a degree of agreement with societal norms not seen in untrained clergy (Finke and Dougherty 2002). Beyond education effects, the gender breakdown of a congregation can influence whether those in same-sex relationships are accepted as members. Congregations with higher percentages of females are more likely to allow same-sex couples to become members. A higher percentage of females does not translate into adopting a welcome statement or allowing lesbians and gays to lead, however. These results both confirm and confound findings at the individual level showing gender differences in the level of acceptance of homosexuality. The final demographic measure, percent of the congregation under 35, does not exhibit a significant association to the dependent variable in any model. Again, this is most likely due to controlling for the differences across religious traditions. Finally, the location of a congregation can influence its stance toward homosexuality. Congregations in the Midwest and West are all more likely to allow same-sex couples to lead compared to congregations in the south. While a somewhat crude measure of location, the significant relationships between regions provide an impetus for further research focused on how 
location and place influence a congregation (Ammerman 1997). Interestingly though, net of all other effects, congregations in urban areas are no different from those in suburban or rural areas.

There are several limitations to this analysis worth mentioning. First, as discussed previously in the data section the NCS-II data comes from a single informant from each congregation which could introduce bias. The key informant may not be intimately aware of such diverse aspects of the congregation. I am also unable to include a measure of the extent to which each congregation has lesbians or gays in committed relationships in their midst. Increased interpersonal contact with gays and lesbians could significantly alter the dynamics within the congregation.

\section{CONCLUSION}

The purpose of this study was to extend what is currently known concerning the responses of religious organizations to homosexuality using a nationally representative sample of congregations in the United States. These results indicate the access of gays and lesbians to religious congregations is clearly limited. This finding is especially noteworthy considering the religious congregation is perhaps the most significant voluntary organizational feature in American society. I further find that the theological and political ideology, demographic composition, location, and religious tradition of a congregation are all important when examining if gay men and lesbians in committed relationships will be accepted or actively welcomed into a religious congregation. The results from this study reinforce many of the findings in previous work investigating the acceptance of homosexuality within congregations while providing an extension of these lines of research by adding a greater level of generalizability. Original findings from this analysis also demonstrate how the aggregate effect of some individual level predictors can influence entire organizations. 
While religious congregations in the United States are not open to the full inclusion of gays and lesbians into congregational life it is possible that the acceptance of homosexuality within congregations will follow the trajectory of other groups who were excluded in the past. For example, divorcees were at times excluded from full inclusion into a religious body but changing societal norms bumped the levels of acceptance toward this group up. Religious groups responded by beginning to include them at much higher levels (Rogers, 1999).

Therefore, it would not be surprising if in 10,20, or 30 years the acceptance of lesbians and gays into congregational life undergoes the same change. Attitudes toward homosexuality are growing more favorable in the wider culture, (see Andersen and Fetner 2008), and this will undoubtedly influence the stances of religious organizations. Congregations will be forced to respond. In colloquial terms, the rising tide may lift all boats. In this way congregations are reciprocally related to the surrounding culture. Congregations function as agents of socialization that can and do influence the thoughts, beliefs, and behaviors of those who attend. Congregations are also made up of individuals who are subject to broader agents of socialization. This suggests that shifts in congregational stances will undoubtedly take place if religious organizations hope to maintain their position in society. ${ }^{12}$ Congregations, even within Evangelical Protestantism, may begin to utilize a "blended approach" when managing the sexual relationships of parishioners, integrating norms from the religious and gay communities (Thomas and Olson 2012).

Due to the cross-sectional nature of this sample, there is no way to know if congregational stances toward lesbians and gays are indeed growing more inclusive or exclusive. There is a panel component to the NCS-II, but the dependent measures used in this study were

\footnotetext{
${ }^{12}$ I am thankful to a reviewer for pointing out the connection between congregations and culture.
} 
not included on the first wave of the survey. Hopefully future iterations of the NCS will include the same questions employed in Wave II and used in this analysis to provide second and third data points, continuing with a panel component. Researchers will then be able to investigate the either growing or declining acceptance of homosexuality into congregational life as well as the effects of demographic shifts within congregations. Future research may also investigate the extent to which individuals opposed to homosexuality are self-selecting into congregations that align with their beliefs (Putnam and Campbell, 2010).

Whatever the future may hold concerning the extent to which religious organizations in the United States will include lesbians and gays into congregational life, the importance of continuing to investigate the topic should be noted. Congregations are the most pervasive public gathering place in our culture and involve more people than any other voluntary organization (Ammerman, 1997; Chaves, 2004; Putnam, 2000). The level to which congregations systematically reject or accept socially relevant minority population provides a unique perspective on the present state of American culture and religion. 


\section{REFERENCES}

Ammerman, Nancy Tatom. 2005. Pillars of faith: American congregations and their partners. Berkeley, CA: University of California Press.

Ammerman, Nancy Tatom, with Arthur E. Farnsley and et al. 1997. Congregation and community. New Brunswick, NJ: Rutgers University Press.

Andersen, Robert and Tina Fetner. 2008. Cohort differences in tolerance of homosexuality: Attitudinal change in Canada and the United States, 1981-2000. Public Opinion Quarterly 72(2):311-330.

Bartkowski, John. 1996. Beyond biblical literalism and inerrancy: Conservative Protestants and the hermeneutic interpretation of scripture. Sociology of Religion 57(3):259-272.

Becker, Penny Edgell. 1999. Congregations in conflict: Cultural models of local religious life. Cambridge: Cambridge University Press.

Beuttler, Fred W. 1999. Making theology matter: Power, polity and the theological debate over homosexual ordination in the Presbyterian church (U.S.A.). Review of Religious Research 41:239-261.

Beyerlein, Kraig, and Mark Chaves. 2003. The Political activities of religious congregations in the United States. Journal for the Scientific Study of Religion 42:229-246.

Burdette, Amy M., Christopher G. Ellison, and Terrence D. Hill. 2005. Conservative Protestantism and tolerance toward homosexuals: An examination of potential mechanisms. Sociological Inquiry 75:177-196.

Burgess, John P. 1999. Framing the homosexuality debate theologically: Lessons from the Presbyterian church (U.S.A.). Review of Religious Research 41:262-274. 
Button, James W., Barbara A. Rienzo, and Kenneth D. Wald. 1997. Private lives, public conflicts: Battles over gay rights in American communities. Washington, D.C.: Congressional Quarterly, Inc.

Cadge, Wendy. 2002. Vital conflicts: The mainline denominations debate homosexuality. In The quiet hand of God: Faith-based activism and the public role of mainline Protestantism, eds. Robert Wuthnow and John H. Evans, 265-286. Berkeley: University of California Press.

Cadge, Wendy, Heather Day, and Christopher Wildeman. 2007. Bridging the denominationcongregation divide: Evangelical Lutheran Church in America congregations respond to homosexuality.” Review of Religious Research 48(3):245-259.

Cadge, Wendy, Jennifer Girouard, Laura R. Olson, Madison Lylerohr. 2012. Uncertainty in clergy’s perspectives on homosexuality: A Research Note. Review of Religious Research doi:10.1007/s13644-012-0058-1.

Cadge, Wendy, Laura R. Olson, and Christopher Wildeman. 2008. How denominational resources influence debate about homosexuality in mainline Protestant congregations." Sociology of Religion 69(2):187-207.

Cadge, Wendy and Christopher Wildeman. 2008. Facilitators and advocates: How mainline Protestant clergy respond to homosexuality. Sociological Perspectives 51(3):587-603.

Chaves, Mark. 2004. Congregations in America. Cambridge, MA: Harvard University Press. Chaves, Mark. 2011. American religion: Contemporary Trends. Princeton, NJ: Princeton University Press. 
Chaves, Mark and Shawna Anderson. 2008. Continuity and change in American congregations: Introducing the second wave of the National Congregations Study. Sociology of Religion 69(4):415-440.

Chaves, Mark, Mary Ellen Konieczny, Kraig Beyerlein, and Emily Barman. 1999. The national congregations study: Background, methods, and selected results. Journal for the Scientific Study of Religion 38:458-476.

Cochran, John K., and Leonard Beeghley. 1991. The influence of religion on attitudes toward nonmarital sexuality: A preliminary assessment of reference group theory. Journal for the Scientific Study of Religion 30:45-62.

Comstock, Gary David. 2001. A whosoever church: Welcoming lesbians and gay men into African American congregations. Louisville, KY: Westminster John Knox Press.

Davis, Nancy J. and Robert V. Robinson. 1996. Are the rumors of war exaggerated? Religious orthodoxy and moral progressivism in America. American Journal of Sociology 102: 756-787.

Djupe, Paul A., Laura R. Olson, and Christopher P. Gilbert. 2006. Whether to adopt statements on homosexuality in two denominations: A research note. Journal for the Scientific Study of Religion 45(4):609-621.

Ellingson, Stephen, Nelson Tebbe, Martha Van Haitsma, and Edward O. Laumann. 2001. Religion and the politics of sexuality. Journal of Contemporary Ethnography 30(1):3-55.

Ellison, Christopher G. and Marc A. Musick. 1993. Southern intolerance: A fundamentalist effect? Social Forces 72(2): 379-398. 
Finke, Roger and Kevin D. Dougherty. 2002. The effects of professional training: The social and religious capital acquired in seminaries. Journal for the Scientific Study of Religion 41(1):103-120.

Finke, Roger and Rodney Stark. 2006. The churching of America, 1776-2005: Winners and losers in our religious economy. New Brunswick, NJ: Rutgers University Press.

Finlay, Barbara and Carol S. Walther. 2003. The relation of religious affiliation, service attendance, and other factors to homophobic attitudes among university students. Review of Religious Research 44(4):370-393.

Frenk, Steven M., Shawna L. Anderson, Mark Chaves, and Nancy Martin. 2011. Assessing the validity of key informant reports about congregations' social composition. Sociology of Religion 72(1):78-90.

Froese, Paul, Christopher D. Bader, and Buster Smith. 2008. Political tolerance and God's wrath in the United States. Sociology of Religion 69:29-44.

Gay, David A., and Christopher G. Ellison. 1993. Religious subcultures and political tolerance: Do denominations still matter? Review of Religious Research 34:311-332.

Greeley, Andrew, and Michael Hout. 2006. The truth about conservative Christians: What they think and what they believe. Chicago, IL: University of Chicago Press.

Haider-Markel, Donald P. and Mark R. Joslyn. 2008. Beliefs about the origins of homosexuality and support for gay rights: An empirical test of attribution theory. Public Opinion Quarterly 72:291-310.

Hartman, Keith. 1996. Congregations in conflict: The battle over homosexuality. New Brunswick, NJ: Rutgers University Press. 
Herek, Gregory M. 1988. Heterosexuals' attitudes toward lesbians and gay men: Correlates and gender differences. The Journal of Sex Research 25:451-477.

Herek, Gregory M. 2002. Gender gaps in public opinion about lesbians and gay men. The Public Opinion Quarterly 66:40-66.

Herek, Gregory M., and John P. Capitanio. 1995. Black heterosexuals' attitudes toward lesbians and gay men in the United States. The Journal of Sex Research 32:95-105.

Hill, Terrence D., Benjamin E. Moulton, and Amy M. Burdette. 2004. Conservative Protestantism and attitudes toward homosexuality: Does political orientation mediate this relationship? Sociological Focus 37:59-70.

Hunter, James Davison. 1992. Culture wars: The struggle to define America. New York, NY: BasicBooks.

Kapinus, Carolyn A., Rachel Kraus, and Daniel R. Flowers. 2010. Excluding inclusivity: Protestant framing of homosexuality. Interdisciplinary Journal of Research on Religion 6 (Article 4). Available at http://www.religjournal.com/pdf/ijrr06004.pdf.

Koch, Jerome R. and Evans W. Curry. 2000. Social context and the Presbyterian gay/lesbian ordination debate: Testing open-systems theory. Review of Religious Research 42(2): 206-215.

LaMar, Lisa and Mary Kite. 1998. Sex differences in attitudes toward gay men and lesbians: A multidimensional perspective. The Journal of Sex Research 35(2):189-196.

Linclon, C. Eric and Lawrence Mamiya. 1990. The black church in the African American experience. Durham, N.C.: Duke University Press.

McDaniel, Eric L. and Christopher G. Ellison. 2008. God's party? Race, religion, and partisanship over time. Political Research Quarterly 61(2):180-191. 
Moon, Dawne. 2004. God, sex, and politics: Homosexuality and everyday theologies. Chicago, IL: The University of Chicago Press.

Olson, Laura R. and Wendy Cadge. 2002. Talking about homosexuality: The views of mainline Protestant clergy. Journal for the Scientific Study of Religion 41(1):153-167.

Olson, Laura R., Wendy Cadge, and James T. Harrison. 2006. Religion and public opinion about same-sex marriage. Social Science Quarterly 87:340-60.

Pampel, Fred C. 2000. Logistic regression: A primer. Thousand Oaks, CA: Sage.

Putnam, Robert D. 2000. Bowling alone: The collapse and revival of American community. New York, NY: Simon and Schuster.

Putnam, Robert D. and David E. Campbell. 2010. American grace: How religion divides and unites us. New York: NY: Simon and Schuster.

Roof, Wade Clark and William McKinney. 1987. American mainline religion. New Brunswick: Rutgers University Press.

Rogers, Jack. 1999. Biblical interpretation regarding homosexuality in the recent history of the Presbyterian church (U.S.A.). Review of Religious Research 41:223-238.

Rubin, Donald B. 1987. Multiple imputation for nonresponse in surveys. New York: Wiley.

Rubin, Donald B. 1996. Multiple imputation after 18+ years. Journal of the American Statistical Association 91(434):473-489.

Scheitle, Christopher P., Stephen M. Merino, and Andrew Moore. 2010. On the varying meaning of 'open and affirming'. Journal of Homosexuality 57:1223-1236.

Schwadel, Philip, and Kevin D. Dougherty. 2010. Assessing key informant methodology in congregational research. Review of Religious Research 51:366-379. 
Sherkat, Darren E., Kylan Mattias de Vries, and Stacia Creek. 2010. Race, religion, and opposition to same-sex marriage. Social Science Quarterly 91(1): 80-98.

Sherkat, Darren E., Melissa Powell-Williams, Gregory Maddox, and Kylan Mattias de Vries. 2011. Religion, politics, and support for same-sex marriage in the United States, 19882008. Social Science Research 40: 167-180.

Smith, Christian, Michael Emerson, Sally Gallagher, Paul Kennedy, and David Sikkink. 1998. American Evangelicalism: Embattled and thriving. Chicago, IL: The University of Chicago Press.

Stark, Rodney and Roger Finke. 2000. Acts of faith: Explaining the human side of religion. Berkeley: University of California Press.

Steensland, Brian, Jerry Z. Park, Mark D. Regnerus, Lynn D. Robinson, W. Bradford Wilcox, and Robert D. Woodberry. 2000. The measure of American religion: Toward improving the state of the art. Social Forces 79(1):291-318.

Stroope, Samuel. 2011. Education and religion: Individual, congregational, and cross-level interaction effects of biblical literalism. Social Science Research 40:1478-1493.

Thomas, Jeremy N. and Daniel V. A. Olson. 2012. Beyond the culture war: Managing sexual relationships inside a congregation of gay Evangelicals. Review of Religious Research doi:10.1007/s13644-012-0051-8.

Van Geest, Fred. 2007a. Changing patterns of denominational political activity in North America: The case of homosexuality. Review of Religious Research 49(2):199-221.

Van Geest, Fred. 2007b. Research note: Christian denominational political action on the subject of homosexuality. Review of Religious Research 48(4):401-419. 
Wald, Kenneth D., James W. Button, and Barbara A. Rienzo. 1996. The politics of gay rights in American communities: Explaining antidiscrimination ordinances and policies. American Journal of Political Science 40(4):1152-1178.

Wald, Kenneth D., Dennis E. Owen, and Samuel S. Hill, Jr. 1988. Churches as political communitites. The American Political Science Review 82(2):531-548.

Warner, R. Stephen. 1995. The Metropolitan Community Churches and the gay agenda: Power of Pentecostalism and essentialism. In Religion and the Social Order: Sex, Lies, and Sanctity: Religion and Deviance in Contemporary North America, ed. D. G. Bromley, M.J. Neitz, and M.S. Goldman, 81-108. Greenwich, CT: JAI Press.

Wellman Jr., James K. 1999. Introduction: The debate over homosexual ordination: Subcultural identity theory in American religious organizations. Review of Religious Research 41:184-206.

Whitehead, Andrew L. 2010. Sacred rites and civil rights: Religion's effect on attitudes toward same-sex unions and the perceived cause of homosexuality. Social Science Quarterly 91:63-78.

Wood, James R. and Jon P. Bloch. 1995. The role of church assemblies in building a civil society: The case of the United Methodist general conference's debate on homosexuality. Sociology of Religion 56(2):121-136.

Wuthnow, Robert. 1988. The restructuring of American religion: Society and faith since World War II. Princeton, NJ: Princeton University Press. 